Article

\title{
Understanding of Sustainability and Education for Sustainable Development among Pre-Service Biology Teachers
}

\author{
Petra Bezeljak $^{1, *\left(\mathbb{D}, \text { Martin Scheuch }^{2}(\mathbb{D} \text { and Gregor Torkar }\right.}{ }^{3}$ \\ 1 Austrian Educational Competence Center for Biology, University of Vienna, 1090 Vienna, Austria \\ 2 University College for Agricultural and Environmental Education, 1130 Vienna, Austria; \\ martin.scheuch@haup.ac.at \\ 3 Faculty of Education, University of Ljubljana, 1000 Ljubljana, Slovenia; gregor.torkar@pef.uni-lj.si \\ * Correspondence: petra.bezeljak@univie.ac.at; Tel.: +43-1-4277-60319
}

Received: 29 June 2020; Accepted: 20 August 2020; Published: 25 August 2020

\begin{abstract}
Sustainable development (SD) is one of the global and central aims of today's politics. As stated in Agenda 21, education must play an essential role in achieving a sustainable society. The present research is focused on Slovenian and Austrian biology teacher students' understanding of SD and education for sustainable development (ESD). The research was carried out at the University of Ljubljana and the University of Vienna. Altogether, 60 Slovenian and 60 Austrian pre-service biology teachers participated in the questionnaire-based study. Pre-service biology teachers answered a set of Likert-type and open survey questions. Less than half of the pre-service biology teachers from Slovenia and Austria had a good understanding of the environmental aspects of SD, but they lack understanding of the interconnections between the environmental, economic and social dimensions related to SD. They describe and connect ESD with environmental education and environmental awareness. Students from both countries know some pedagogical principles of ESD, such as active learning and transformative education. Analysis with the sustainable development goals (SDGs) in focus showed that only some of them were mentioned by the teacher students. The results of the research contribute to the evaluation and development of curriculum for middle and high school biology teachers.
\end{abstract}

Keywords: attitudes; knowledge; 17 SDGs; pre-service biology teachers; sustainable development; teacher education

\section{Introduction}

One of the most important goals of humanity in the 21st century is to construct a sustainable society. Education is one of the keys for achieving sustainability and also one of the targets for a sustainable society [1]. The term sustainable development (SD) was first mentioned by Carlowitz [2] in the book, Silvicultura oeconomica (1713), and was described as a principle in the field of forestry. Nowadays, Brundtland's definition of SD as "development that meets the needs of the present without compromising the ability of future generations to meet their own needs" [3] (p. 43) has become well known. This concept has received the most attention since the United Nations Conference on Environment and Development, held in Rio de Janeiro in 1992. The key document of the Rio agreement is called Agenda 21 [4] and is a major action plan for SD in the 21st century [5]. The core concept of strong sustainability is that the benefits of nature are irreplaceable and that the entire economy is reliant on society, which in turn is entirely dependent on the environment. This emphasizes the interdependencies between our society, our economy and the natural environment [6,7]. Human survival is directly tied to our relationship with the natural environment; therefore, it is essential 
to establish a sustainable lifestyle that depends on a balance between individuals' consumption and the capacity of the natural environment for renewal [8]. Some researchers perceive ecological systems as a known fixed boundary inside of which all human social systems must exist and economic systems as existing within the boundaries of social systems [9].

Education for sustainable development (ESD) is one of the main aims of the national as well as international educational policies [10]. ESD was first mentioned by Chapter 36 of Agenda 21, where four main aims of the work of ESD were described: improve basic education, reorient existing education to address SD and develop public understanding, awareness and training [4]. For (future) teachers it is essential to raise awareness about SD and ESD [11]. Nowadays, SD is the theoretical basis and an increasingly important norm for human development worldwide [1]. Science education, including and as a part of it biology education, plays an important role for SD and ESD, as van Eijck and Roth [12] have pointed out. SD in education is a framework for orientation, for selecting topics and for developing educational settings [13].

The United Nations Decade for ESD (2005-2014) was followed by the Global Action Plan (GAP) on ESD, designed to provide core learning content and approaches for the post-2015 ESD agenda. Seventeen sustainable development goals (SDGs) are the core elements of Agenda 2030. SDG 4 is focused on quality education: "Ensure inclusive and equitable quality education and promote lifelong learning opportunities for all" [14]. ESD is an approach to education, which includes an integrative and holistic view, linking knowledge and action. Kopnina [15] has criticized weak models of sustainability, as, for example, quoted above. On this basis, she also suggests new concepts of ESD, which are more ecocentric. It should be an education for environmental issues, including social and ecological sustainability, as opposed to an anthropocentric view with the economic aspects as a starting point and environmental aspects as resource issues for the economy or an affected domain due to economic activities. Selby [16] argues that the current de-natured nature of ESD makes it unlikely that the student will become motivated to care and act for nature. According to the author, nature is only accorded instrumental and utilitarian value in ESD.

\section{Education for Sustainable Development in Teacher Education}

We can find many models of how to include ESD in general teaching and biology education. All these models comprise a multi-level process. Models include societal issues (at local, regional, global levels) and inter- and multidisciplinary approaches as well as changes in pedagogy. ESD teaching and learning is a combination of different views and taking on different perspectives, frequently dealing with socially relevant topics, biology in combination with chemistry and/or physics and the three pillars of sustainability: social, economic and ecological. The aim of teaching follows a skill-orientated paradigm [17] or, more recently, a competencies-driven discussion [18]. Topics in the context of a sustainable future include biodiversity, climate change, the sustainable use of natural resources (e.g., soil, water, energy, ... ), health, cultural heritage, multiculturalism and global welfare [10]. One example of an ESD case study in research literature is the work on a local watershed by Eijck and Roth [12]. These authors studied the complexity of human-nature interactions, but at the same time, they made in-depth physical, chemical and biological observations to link everything together and start thinking about solutions for prevalent problems at hand. Another exemplary work is about the return of the wolf as a case for ESD in Germany and looks at how the topic is valued by pre-service teachers for implementing in schools [19].

One of the main critical issues for teachers is to discuss with students the effects of students' behavior and sustainable practice in the local environment. Other important goals are to learn negotiation, problem-solving and decision-making skills through discussions about ecological, social, economic and ethical principles concerning local and global responsibility in their own lives. Through memorable, experiential and active processes, students learn to discuss their values and to critically select and evaluate sources of information [20]. It is essential to present biology as action-oriented science education, where students are engaged in socio-political actions and start making a change [21]. 
Torkar [22] reports that Slovene in-service biology teachers under-emphasize the importance of students' interactive participation in environmental actions. They have encouraged them to analyze and discuss problems rather than to empower them to take proactive roles, which would provide them with the necessary experiences to actively participate in societal change. Participation of youth is a central feature in the development of citizenship and youth development [23].

Understanding SD and ESD are nowadays one of the critical competencies for future teachers worldwide [7,24-27]. National strategies for ESD have been developed in the formal education systems of Austria and Slovenia [28-30]. ESD is increasingly achieving an interdisciplinary role in the curricula from kindergarten to the university level. SD goals are integrated into biology and other biology-related subjects at the lower and upper secondary school level in Slovenia and Austria.

From the curricula for biology in Slovenian lower secondary school (8th and 9th grade), SD is directly mentioned in the 9th grade in the context of biology and society and human impact on the environment [31]. Sustainability is also mentioned as one of the key goals in science subjects in the 6th and 7th grade of the lower secondary school [32]. In the Austrian curricula for biology and environmental education that we investigated, SD is mentioned in all of the four grades of lower secondary school in the context of humans and health, animals and plants, and ecology and environment [33]. In upper secondary school, SD is mentioned in the context of ecology and environment in 10th and 11th grade [34]. These above-mentioned concepts in biology education and ESD as well as the curricular demands require well-prepared, competent biology teachers. As far as we know, no previous research has investigated the understanding of sustainability and ESD among student teachers of biology in Slovenia and Austria. Slovenian researchers have already studied the SD understanding of preschool teachers [35] and among future primary school teachers [36]. Future primary school teachers (a little more than $40 \%$ ) connect the term SD with the conservation of nature and other goods for future generations (Bruntland's definition of SD), and the most frequent description of ESD ( $27 \%$ of students) is teaching and informing pupils about environmental pollution or the importance of a clean environment. Torkar [37] studied students' views on the acceptability of their teachers' value-related statements about sustainability and climate change and results show that students expect their teachers to promote the concepts of SD.

International network ENSI (Environment and School Initiatives: www.ensi.org) has supported educational developments, environmental understanding, active approaches to teaching and learning in the fields of EE and ESD [38]. Austrian researchers report on the desired competences for ESD in teacher education [26], which were developed in a European cooperation project. There is an established school and university college network for promoting ESD in the formal education system in Austria (www.oekolog.at). Heinrich [39] looked at selected students' perspectives on SD in Austria within Ökolog and discovered that the school system produces tensions with daily and non-sustainable routines on the one hand and imperatives about sustainable behavior on the other. Rauch and Pfaffenwimmer [40] studied this network for innovation in ESD in the school system, and Ucsnik [41] did so from a political perspective. In international studies, we found more studies among student teachers and their understanding of sustainability and ESD. Summers et al. [42] analyzed subject matter knowledge of science teacher trainees regarding SD in the field of geography. Burmeister and Eilks [7] described the understanding of sustainability and ESD among German student teachers and trainee teachers of chemistry. The results show that student teachers and trainee teachers of chemistry show positive attitudes towards ESD in chemistry education but lack clear theory supported concepts about SD and ESD. The Ceulemans and Eilks article [43] about experienced Flemish chemistry teachers and their knowledge regarding sustainability was based on the same questionnaire. They report that experienced Flemish chemistry teachers have limited knowledge about SD and ESD, with the main sources of knowledge mentioned being the media or other personal information channels and which did not include school initiatives or further education programs. Palmberg et al. [44] researched teaching methods in biology education and sustainability education used to promote sustainability. The results indicate that the most commonly mentioned teaching methods were those in which students worked 
in groups and participated actively in learning processes. Maurer and Bogner [45] researched freshmen perception of environmental education and ESD. Results show that family, school (especially teachers), outreach and media are the most important sources of knowledge about EE and ESD.

Therefore, different studies recognized positive attitudes towards concepts of SD and ESD, but also the lack of theoretical knowledge and interconnections between different aspects of sustainability. A new political document, global action plan (GAP) [1], has also influenced ESD greatly in the past three years. Introduction of SDGs as a commonly shared political document also affects ESD. One way of dealing with this new situation was proposed by Kioupi and Voulvoulis [46], taking the sub-points of the SDGs as desired endpoints of developments and the different steps in education, which are necessary for making substantial progress. The three-pillar model of sustainability was pushed to the background in the discussion, maybe because it was too coarse for everyday politics. As a different approach, the 17 SDGs with many more sub-indicators take a different approach insofar as they are very concrete ways to reach each of the aims. Therefore, a great fragmentation of the overall topic of sustainability took place. For our study, we followed the critique of Kopnina [15], which states that there are anthropocentric and ecocentric motives in SD, and we therefore take these two positions as underlying thinking structures into consideration for our study.

\section{Research Problem}

The study aimed to identify knowledge and understanding about SD and ESD among Slovenian and Austrian pre-service biology teachers and compare the results between the two countries. We think a comparative view on two cohorts of biology teacher students in neighboring countries with different study programs can help to understand commonalities and differences in their knowledge and understanding. The research also focused on pre-service biology teachers' willingness to implement ESD in their future teaching. Moreover, the open answers were analyzed to look for the 17 SDGs and how they are being covered by the examples given.

\section{Materials and Methods}

The research was based on descriptive and causal non-experimental research methods. In this research, qualitative and quantitative methods were used, with quantifying methods in analysis being used to extract the essence of the qualitative answers. A questionnaire was used to collect data. Finally, a comparative approach helped us to elaborate conclusions.

\subsection{Sample and Settings}

Pre-service biology teachers from the University of Ljubljana and the University of Vienna participated in the research. The first sample was 60 students from the University of Ljubljana, Faculty of Education, Department of Biology, Chemistry and Home Economics. The second sample was 60 pre-service biology teachers from the University of Vienna, Centre for Teacher Education.

The study was conducted in May and June 2018. Students completed the anonymous paper-and-pencil questionnaire in 15 to $20 \mathrm{~min}$. Firstly, the instructions and the general goals of the research were presented to the students. The sample was non-randomly chosen. From the University of Ljubljana, more than $80 \%$ of future biology teachers from the 3rd and 4th year of bachelor study and from the 1st year of a master's course were reached. At the University of Vienna, Centre for Teacher Education, the same number of future biology teachers represented less than $40 \%$ of future biology teaches from the 3rd and 4th year of a bachelor course and the expiring diploma course (this was the study program as it existed before the Bologna architecture of bachelor and master graduation was implemented in the academic year 2014/15).

Student teachers from Slovenia and Austria had different second subjects of study. Slovene students at the University of Ljubljana studying the two-subject teacher education program can select home economics or chemistry as the second subject. In the sample, $52 \%$ of students chose home economics and $48 \%$ chemistry. At the University of Vienna, the study program for biology teachers is called 
Biology and Environmental Education. Students can choose it in combination with one of 27 other subjects. The combinations were with geography (15\%), psychology and philosophy $(15 \%)$, German language (13\%), home economics $(10 \%)$, Spanish language $(8 \%)$, English language $(7 \%)$, math $(7 \%)$, sport $(7 \%)$, chemistry $(5 \%)$, French language $(5 \%)$ and other subjects $(8 \%)$.

\subsection{Instrument}

The questionnaire developed by Burmeister and Eilks [7] was used. The questionnaire was originally developed in the German language and for chemistry teachers. It was slightly modified (one question was added: "Write 15 words you associate with the term sustainability") in order to serve for pre-service biology teachers; moreover, it was translated into Slovenian. The questionnaire included open questions and closed questions with Likert-scale response options (four levels of agreement). In the first part of the questionnaire, pre-service teachers answered questions about socio-demographic information, study program and their level of education. In the second part, students answered four open questions. In the first question, students wrote 15 words they associated with the term "sustainability". In the next two questions, students had to describe and define SD and ESD. The last question in this set was about the appropriate school subject in which students could best deal with ESD. The third part of the questionnaire focused on more modern concepts of sustainability: where did participants hear about the most recent concepts (in universities, in the media, etc.) and where did participants hear about ESD.

\subsection{Data Analysis}

All data, as well as the written answers from the paper-pencil questionnaires, were digitized and translated from the Slovenian and German languages to English. First, the closed questions were analyzed using the statistical program IBM ${ }^{\circledR}$ SPSS ${ }^{\circledR}$ Statistics version 24 Data obtained from the questionnaire were processed on the level of descriptive and inferential interfering statistics, using the following statistical methods: $t$-test for Independent Samples and a chi-square test were used to compare the differences between Slovenian and Austrian students' knowledge and attitudes. The level of significance is 0.05 ; the corresponding confidence level is $95 \%$. Secondly, open questions were coded. Coding is the interpretive process by which data are broken down analytically [47]. Deductive and inductive coding methods were used. The categories were taken from the Burmester and Eilks' study [7] and derived from SDGs literature [1] and finally from the material itself. Some categorizations were later redefined and added, based on data material and the theoretical framework. For other open questions, categorizations were created based on the data materials and literature review $[15,18,48]$. Therefore, we coarsely grouped the SDGs into those two categories, anthropomorphic and ecocentric, for the analysis. We are aware that this is only a rough categorization, because the mainly anthropocentric SDG 6 "clean water and sanitation", which was classified as anthropocentric, includes 6.6 "protect and restore water-related ecosystems, including mountains, forests, wetlands, rivers, aquifers and lakes", a clearly ecocentric goal. An example in reverse would be SDG 14, which was classified as ecocentric, but includes, for example, 14.4 according to which sustainable production of seafood is the indicator. Data (associations/words/sentences) with the same meaning were coded together. In our research, data that appeared less than three times per question were not coded. This represented $2 \%$ of all the answers. The frequency of the codes in each category was calculated as a percentage of the whole cohort in our study.

\section{Results}

The following chapters report the current situation on the matter among pre-service biology teachers in Slovenia and Austria. Results are divided into three main sections: SD and SDGs, sources of knowledge about SD and ESD. We compare the results of Slovenian and Austrian students in order to contribute to further development of teacher education programs. 


\subsection{Sustainable Development (SD) and SDGs}

Data obtained from students' answers ( $n=1104)$ to the word "sustainability" were coded into the categories presented in Figure 1. Students strongly linked the term sustainability to environmental aspects and rarely to economic and social aspects of the concept. They also emphasized the time issue in relation to sustainability, meaning mainly long-term thinking, the importance of education for sustainability or simply reproduced the Brundtland's definition of SD. Some responses are more frequently mentioned in one of the two cohorts (Appendix A, Table A1). The Slovenian students mentioned green chemistry, the European Union, home economics and students' competences. Meanwhile, the Austrian students gave answers such as ecological footprint, vegan and vegetarian lifestyle, environmentally friendly, environmental organizations, wildlife conservation, rainforest protection, local products, seasonal products, agriculture and genetically modified organisms, global thinking and First World vs. Third World countries. Differences in associations between the two cohorts could be associated with the curricula, the second subject of study, content knowledge or the differing influences of the mass media in each country.

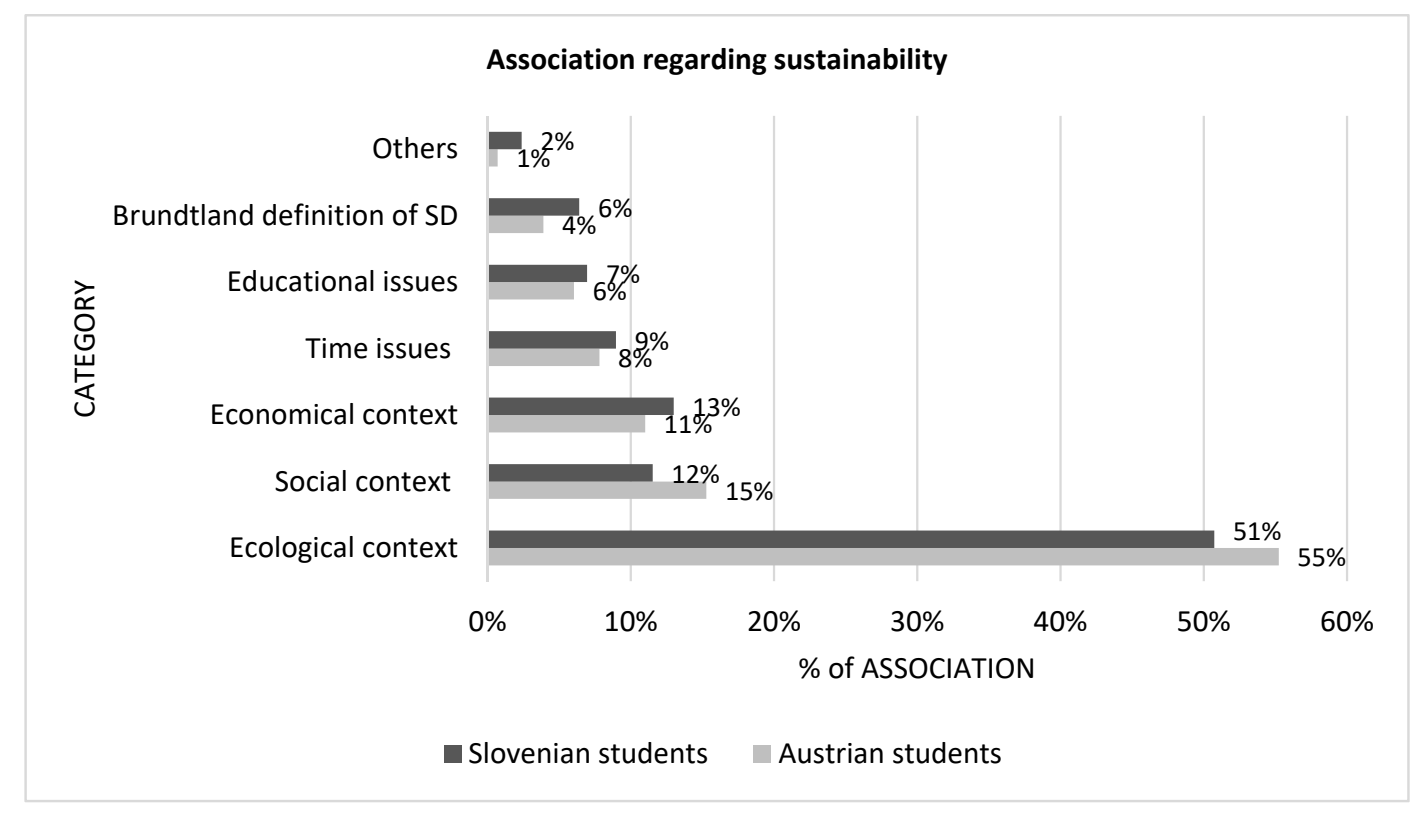

Figure 1. Slovenian (SI) and Austrian (A) students' associations $(n=1104)$ with the term "sustainability" in main categories.

In Table 1 , only the most frequent associations are presented ( $<15$ mentions) and classified according to Figure 2. A few associations (future, sustainable development,) are not classified because of generality. Maybe due to the study group (all are future biology teachers), the ecocentric considerations also have some representation in the analyzed data (Table 1).

Table 1. Categorization of students' answers.

\begin{tabular}{cl}
\hline Category & \multicolumn{1}{c}{ Students' Answers } \\
\hline Egocentrism & - \\
\hline Anthropocentrism & $\begin{array}{l}\text { consumption, ecolabels, education, energy conservation, future generations, } \\
\text { health, pollution, renewable energy sources, recycling, values, waste management }\end{array}$ \\
\hline In between ecocentrism and anthropocentrism & $\begin{array}{l}\text { ecological footprint, environmental conservation, extinction of species, nature } \\
\text { conservation, organic production, time, water conservation }\end{array}$ \\
\hline Ecocentrism & biology, environment, nature \\
\hline
\end{tabular}




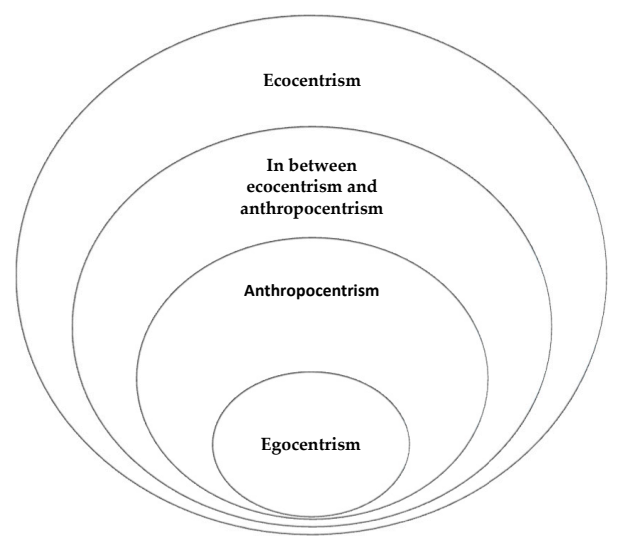

Figure 2. Categorization of students' answers.

Purely egocentric positions could not be found, but anthropocentrism was dominant. In this conception, the demands of people are a central motive and natural factors are only used as resources for human benefit regardless of their value or scarcity. In the transition towards ecocentrism, human needs are still arguments for acting but with more care about nature or natural resources. Finally, ecocentrism was also found, where nature and natural resources are protected for themselves, without a secondary function or effects for human benefits as justification.

Classification of students' associations with the term sustainability was made in order to illustrate which SDGs predominate in their understanding of the subject matter (Figure 3). These findings imply that students' perception of sustainability has not yet reached the full shift to being actively committed to the wellbeing of everyone, including the yet unborn, regardless of gender, economic status, race, religion, age, place of residence, species, etc. as well as the ecocentric positions. The concepts show mainly human-related thinking, with anthropocentric or transitional thinking (compare to results above).

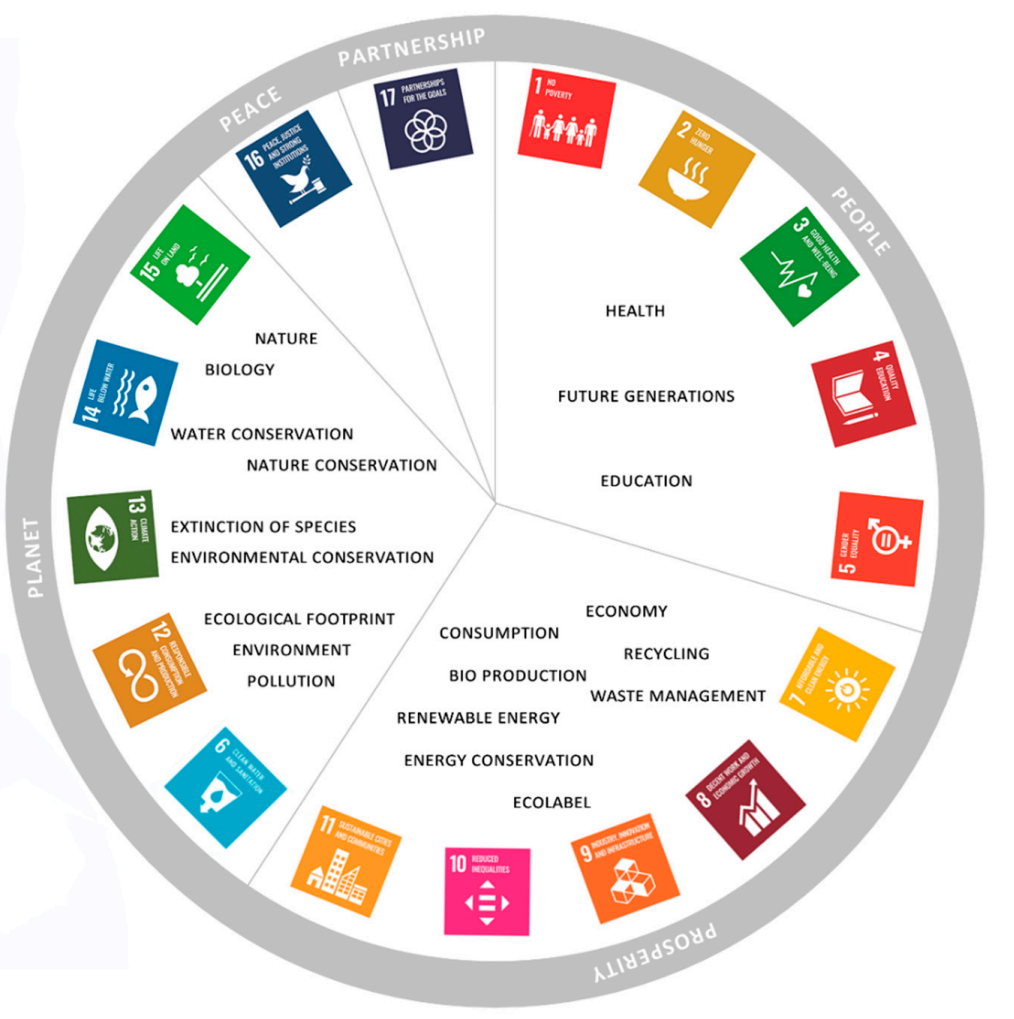

Figure 3. Categorization of students' answers based on the OECD model [49]. 


\subsection{Education for Sustainable Development (ESD)}

Students were asked to explain how they would define/describe ESD. Figure 4 shows that students had an abstract understanding of ESD, linking it to environmental education and describing pedagogical approaches (students' answers are in Appendix A, Table A2).

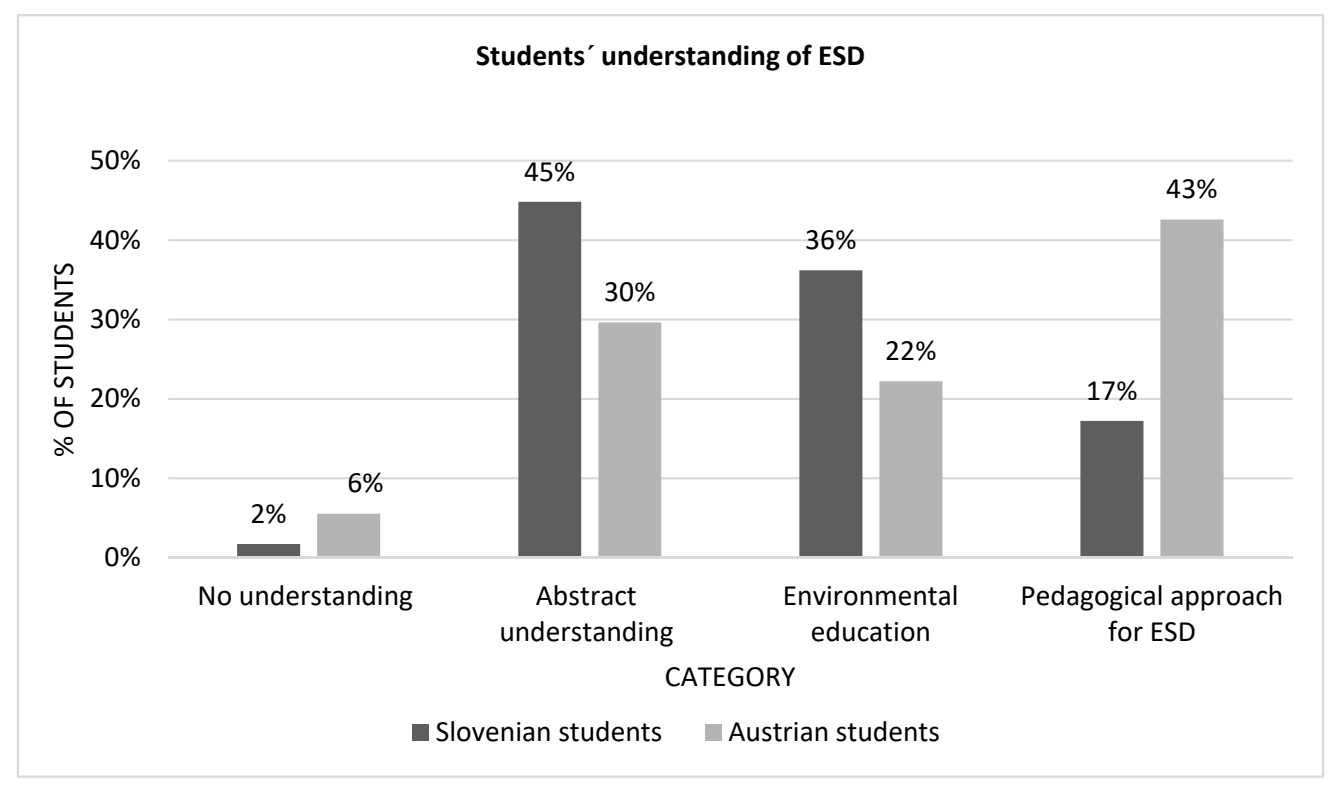

Figure 4. Slovenian and Austrian students' understanding of education for sustainable development (ESD).

Abstract understanding means that students mentioned few ideas about education in relation to sustainability, and those they did were very general and vague. Exemplary answers were, "Teaching about ESD, following the trends in education" or "To bring the so-called concepts closer to everyone, especially in school." Most of the Slovenian students had an abstract understanding. Second, most of the students from Slovenia defined ESD as environmental education. Meanwhile, most students from Austria defined it as a pedagogical approach for teaching about SD. Environmental education was described as learning about environmental protection and creating environmental awareness. Exemplary answers were, "Activating awareness and making people aware of problems that affect the future of our environment" or "Paying attention to environmental impact that is bad for the environment! Everyone can do something! Ecological Footprints Create awareness!" The pedagogical approach was defined as teaching methods that were recommended by ESD (e.g., lifelong learning, working with students' values and competencies, learning by case studies, etc.). Exemplary answers were, "Sustainable thinking exists on a holistic level and must include the environment in which the students live. Therefore, sustainability issues need to be communicated to students on a holistic level."

Students were asked which school subjects might be best for promoting ESD in school. We divided subjects into four main categories: natural science subjects (biology, chemistry and physics), interdisciplinary subjects (geography and home economics), humanities subjects (languages, philosophy and psychology, history) and others (sport, math).

Figure 5 shows that the participants acknowledged the significant role of natural science subjects. $60 \%$ of Slovenian students and $42 \%$ of Austrian students preferred natural science subjects. Biology was the most frequently mentioned subject in both cohorts. In the Slovenian cohort, the second most mentioned category was interdisciplinary subjects; in first place was home economics and in second place, geography. In the Austrian cohorts, the second most mentioned subjects were the humanities subjects, such as languages and psychology. Austrian students more often preferred humanities subjects compared to the Slovenian ones. This may be connected with their study choice (i.e., more than $70 \%$ of Austrian students had chosen an interdisciplinary subject or humanities subject as their second 
subject area). The majority of the participating students mentioned their second study subject as also appropriate for promoting ESD. Given that the second subject choices of the participating students were very diverse, it can be argued that ESD can be meaningfully implemented in very different school subjects and subject areas.

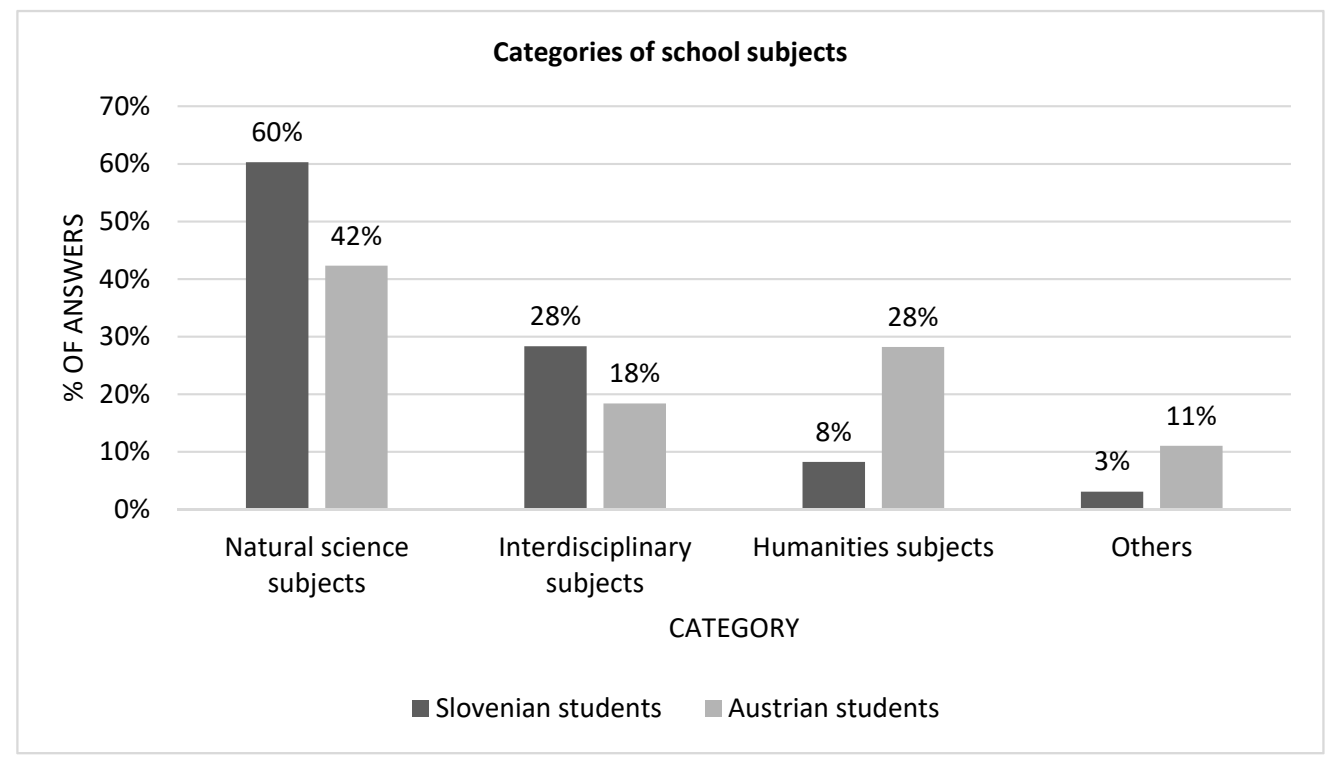

Figure 5. Categories of school subjects.

In Figure 6, it is shown that students from Slovenia and Austria significantly differ regarding implementation of ESD in upper secondary school $(t=2.450, d f=118, p=0.016)$. In this regard, more Slovenian students $(M=3.70, S D=0.619)$ want to implement ESD in upper secondary school than Austrian students $(M=3.25, S D=0.895)$. No statistically significant difference was recorded between Slovenian and Austrian students' attitudes to implementing ESD in lower secondary school $(t=1.233, d f=118, p=0.220)$ and their own class $(t=0.875, d f=118, p=0.383)$. Students in both cohorts showed high levels of support for the importance of ESD in society in general as well as in biology education.

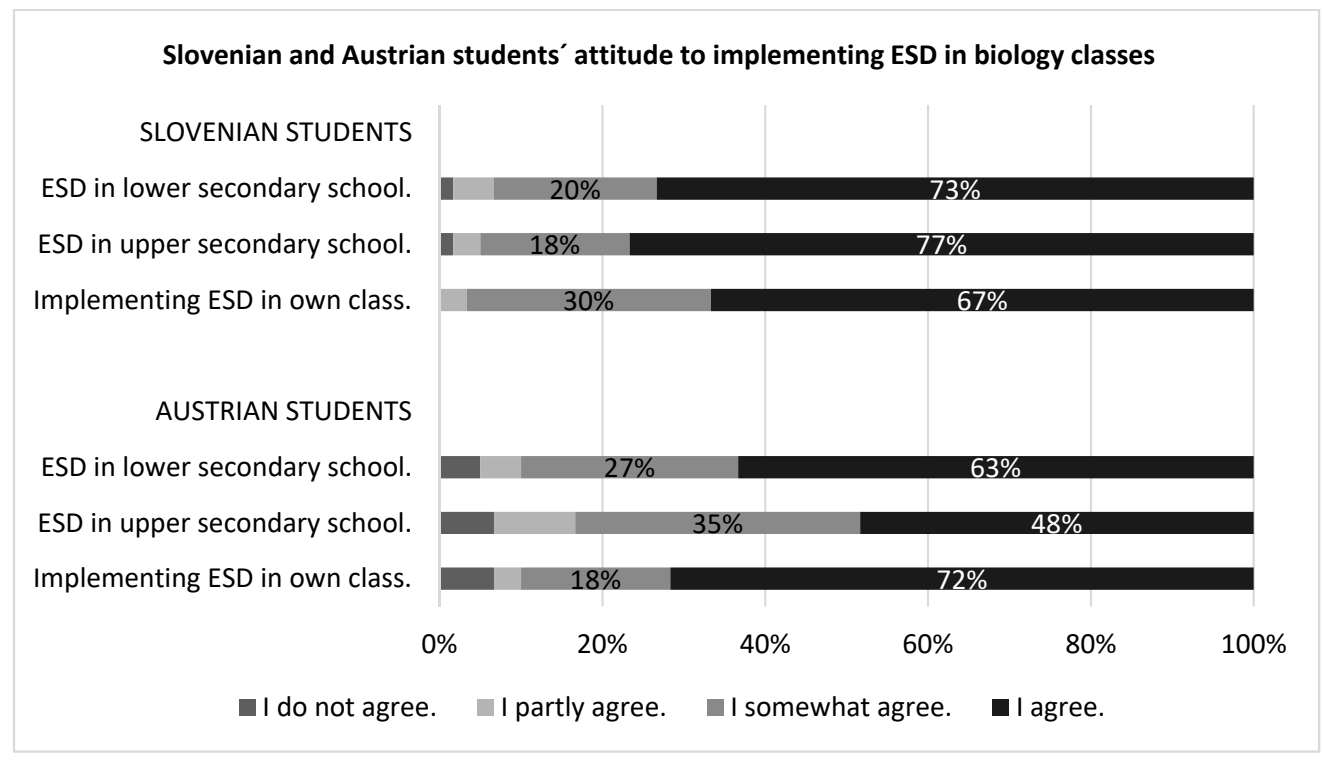

Figure 6. Slovenian and Austrian students' attitude to implementing ESD in biology classes. 


\subsection{Sources of Knowledge about ESD}

Students were asked what their main source of knowledge regarding the three pillars of sustainability was: Brundtland's definition of sustainability or education for SD. Their responses reflected the influence of their biology study, second subject of study, educational study (general didactics, educational psychology, etc.) and other sources external to the university (such as mass media, social media, personal channels). Students' reflection on their sources of knowledge showed differences between Slovenian and Austrian students' answers (Figures 7 and 8). A Pearson Chi Square test was conducted to determine the significance of differences between Slovenian and Austrian students' sources of knowledge. More than half of the students from both cohorts heard about the three pillars of sustainability in their biology courses. A statistically significant difference between the cohorts from biology was found regarding their recall of Brundtland's definition $\left(\chi^{2}=10.096\right.$, $d f=2, p=0.006)$ and ESD $\left(\chi^{2}=59.200, d f=2, p<0.001\right)$. Approximately $40 \%$ of Slovenian students and $60 \%$ of Austrian students remembered Brundtland's definition from their biology studies.

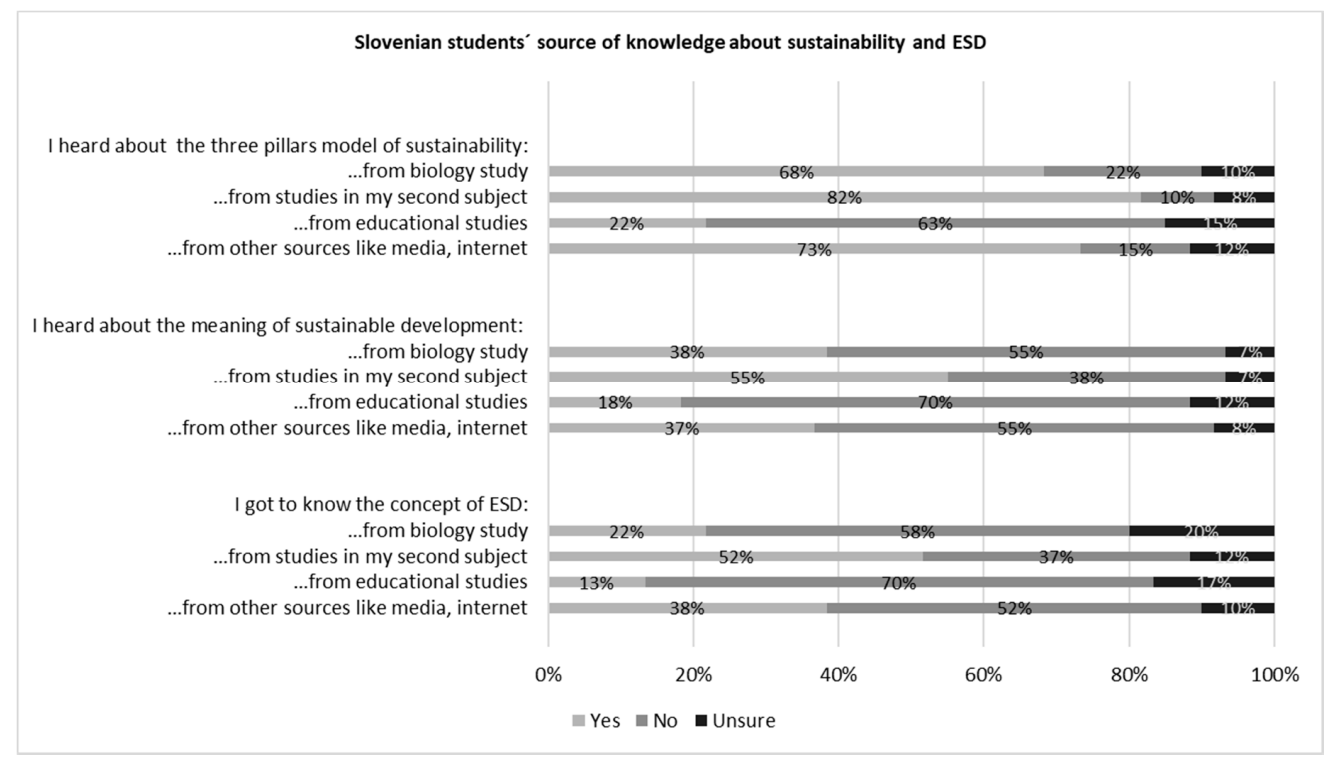

Figure 7. Slovenian students' source of knowledge about sustainability and ESD.

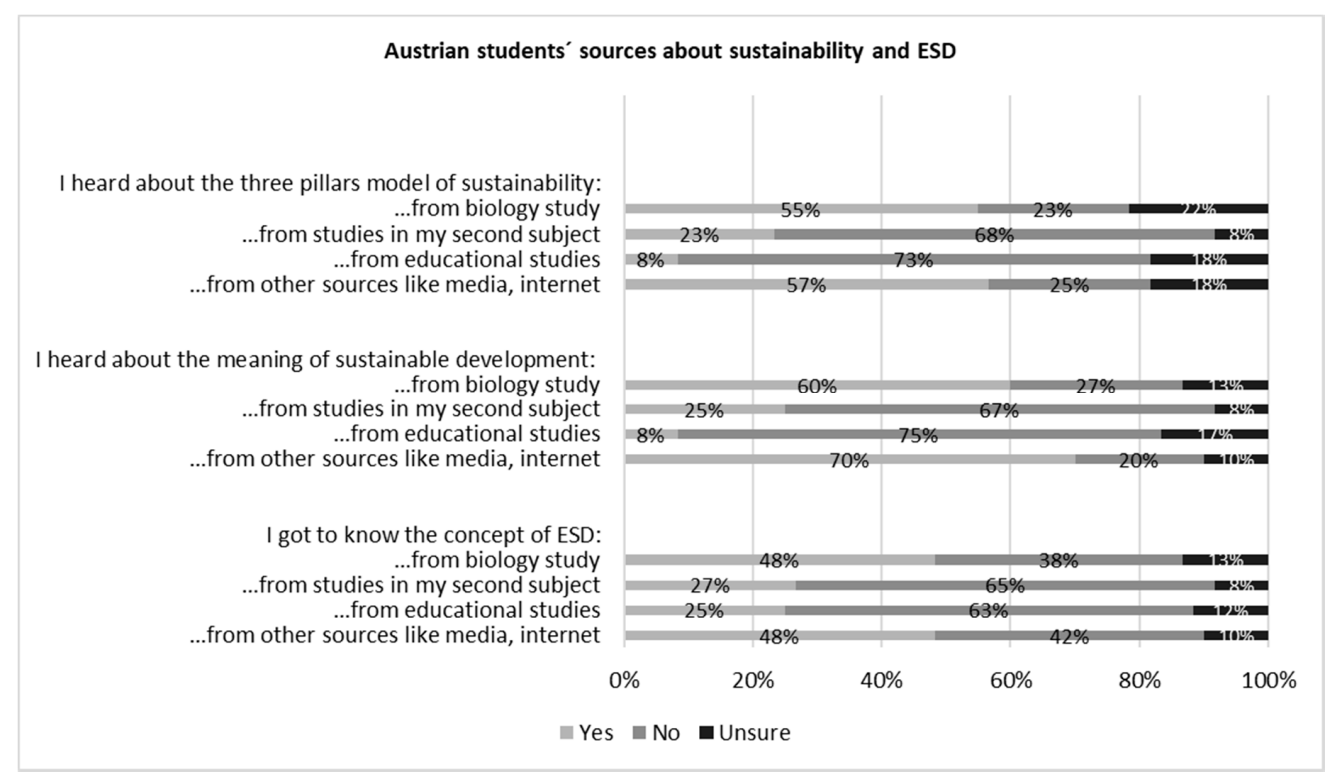

Figure 8. Austrian students' source of knowledge about sustainability and ESD. 
In both cohorts, students have courses where they learn about sustainability. For example, pre-service biology and home economics teachers at the University of Ljubljana attend the compulsory subjects "Consumer Education" and "Population and Environment". They can also attend elective courses such as "Environment and SD". Austrian students can select among 27 subject areas; more than $70 \%$ of those are social science subjects. Some of them, such as geography, include many courses about sustainability issues; one of them is on the human use of natural resources and human-environment interactions. Pre-service biology teachers at the University of Vienna attend the compulsory subject "Cross-sectional Topics in Teaching Biology", one of the topics of which is "Education for Sustainable Development". Austrian students mentioned the biology subject as a main source of knowledge about ESD, while the second subject was emphasized more in the Slovene cohort. Other sources, such as mass media, have been found to be an influential channel of information for students.

\section{Discussion and Conclusions}

This study tried foremost to sketch the actual situation on the knowledge about SD and ESD of two biology teacher student cohorts in Slovenia and Austria. Through comparison and discussion of these results, ideas and recommendations for further improvement of teacher education for sustainable development were developed.

The majority of pre-service biology teachers in Slovenia and Austria similarly perceived SD in connection with ideas taken from the Brundtland's concept of SD, i.e., all three aspects of sustainability and/or inter-generational equitability. Overall, environmental aspects dominate within their perception and there is much less awareness of the complexity of sustainability issues and even less of social and intergenerational equity. Moreover, in grouping the associations about the SDGs in a continuum from egocentric towards ecocentric, we found that most of the thinking about sustainability is done from an anthropocentric position, which is in line with a critique of the concept addressed by Selby [16] stating that the perception of nature and the natural world are limited and decidedly anthropocentric in tone. This is not problematic per se but has to be reflected to enable changing perspectives, which is an important issue in ESD.

The findings are consistent with findings by Hagevik et al. [50] where they report that primary school science teachers have a lack of understanding of the interrelations between different approaches to sustainability. Summers et al. [42] reported quite similar results in their research among English student teachers of science and geography, and Uitto and Saloranta [51] found similar issues in understanding of sustainability dimensions among Finnish lower secondary school teachers. They report that science teachers, especially biology and geography teachers, considered the ecological aspect of sustainability more than the economic or social ones. This applies to the inclusion of other topics into sustainability discourses in addition to environmental issues.

A very important result of the present research, which should be further investigated and elaborated, is the impact of the second study area on pre-service biology teachers' understanding of SD and ESD. The second subject of study varies a great deal between Slovenian and Austrian students, and this may contribute to the differences in the conception of sustainability. Slovenian students can study biology with either home economics or chemistry. Most of the Austrian students combine biology studies with one of the social science subjects. The significant difference in teaching in upper secondary school (Austrian students mentioned this to a lesser degree) might have its basis in the second subject as well as in the curricula and the prescribed topics. Home economics and chemistry could be much more clearly linked to sustainability issues than the broad range of subjects in Austria. Nonetheless, Austrian students reported, like the Slovenian students, that biology studies are their first source of knowledge. From this result, much more inclusion of SD in all subjects of teacher education is needed.

When comparing our results to Burmeister and Eilks' study [7], it must be also pointed out that Slovene and Austrian students were more able to clearly outline the aims and pedagogy of ESD. In line with Ceulemans and Eilks' study [43], most of the answers occurred in the categories of abstract 
understanding and environmental education. This could be a consequence of the UNESCO decade; the previous studies were conducted during, while this study was carried out after that decade. Therefore, it is possible that they describe ESD as an approach to education, which includes an integrative and holistic view linking knowledge and action. There are no major differences between Slovenian and Austrian pre-service biology teachers. They mostly describe ESD as environmental education and environmental awareness. Only a few students possessed clear, theory-based concepts about SD and ESD. Pre-service biology teachers report learning about the concepts of SD and ESD from courses in biology studies, the second study subject, and from the mass media. For pre-service biology teachers in Slovenia, the second subject of study (chemistry or home economics) was a more important source of information about SD and ESD than for their colleagues from Austria. Pre-service biology teachers from Austria heard more about these concepts in the mass media.

Interestingly, the students mentioned educational studies only to a small degree. Since pedagogy is a central pillar in the studies of all student teachers of all subjects, we claim that ESD within educational studies should be strengthened in both countries. This presents the possibility that SD and ESD are not tied to a subject's logical structure and would make it a more cross-sectional topic in teacher education. ESD can be meaningfully implemented in very different school subjects. An interdisciplinary approach in the development of the curriculum of two-subject teachers would be advantageous because SD and ESD are cross-curricular topics that should be addressed in the natural sciences, social sciences and humanities alike. ESD teacher training must be improved and enriched; all sciences and disciplines should contribute with different perspectives to learning about and for SDGs.

Furthermore, greater emphasis should be given to research on the perception and practice of SD and ESD among teachers before and during service. These results can serve in the planning of longitudinal research that focuses on changes in students' SD and ESD understanding from the first to the last semester at university. This will provide a better insight into the impact of higher education programs on students' understanding of SD and ESD.

Author Contributions: P.B. conducted the study and wrote the paper. M.S. and G.T. supervised the study, discussed the qualitative analysis and worked on the paper. All authors have read and agreed to the published version of the manuscript.

Funding: The University of Vienna, the University of Ljubljana and University College for Agricultural and Environmental Education funded this research.

Acknowledgments: We wish to thank the participating students and Open Access Funding by the University of Vienna.

Conflicts of Interest: The authors declare no conflict of interest.

\section{Appendix A}

Table A1. Slovenian (SI) and Austrian (A) students' associations about the term sustainability.

\begin{tabular}{|c|c|c|c|}
\hline NO & Category & $\begin{array}{c}\text { Number of Answers } \\
\left(f S I^{1} / A^{2} / T^{3}\right) \\
(f \% S I / A / T)\end{array}$ & Answers Included in the Category and Their Frequency $(f S I / A / T)$ \\
\hline 1 & $\begin{array}{c}\text { Ecological } \\
\text { context }\end{array}$ & $\begin{array}{l}(f 277 / 311 / 588) \\
(f \% 51 / 55 / 53)\end{array}$ & 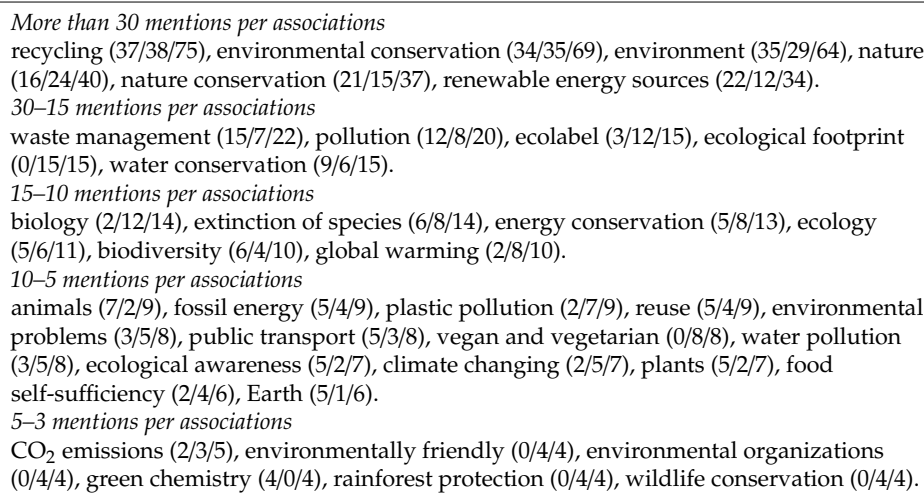 \\
\hline
\end{tabular}


Table A1. Cont.

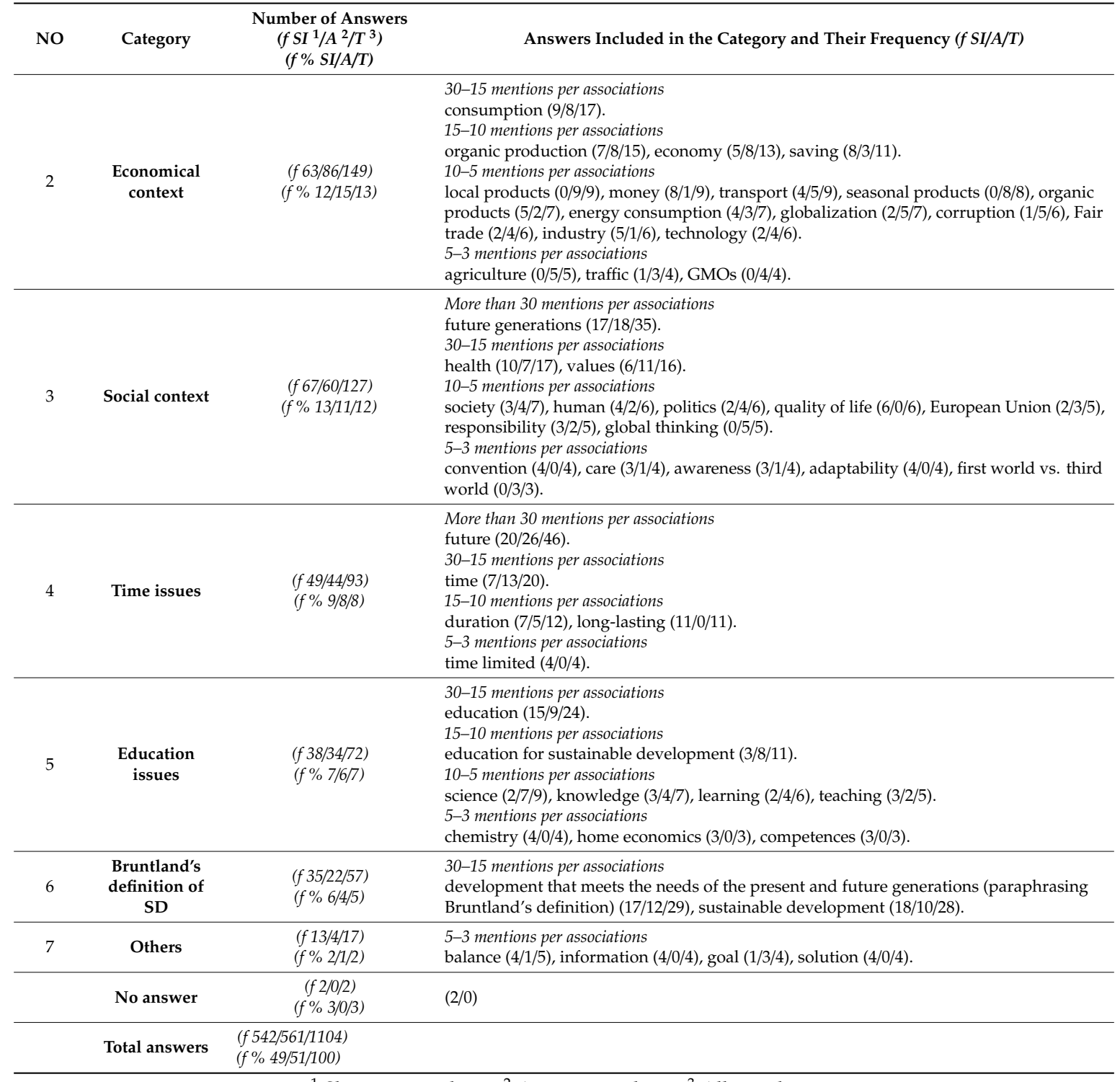

${ }^{1}$ Slovenian students. ${ }^{2}$ Austrian students. ${ }^{3}$ All together.

Table A2. Students' understanding of ESD.

\begin{tabular}{|c|c|c|c|}
\hline NO & Category & $\begin{array}{c}\text { Number of Answers } \\
(f S I / A / T) \\
(f \% S I / A / T)\end{array}$ & Typical Answers \\
\hline 1 & $\begin{array}{c}\text { No } \\
\text { understanding }\end{array}$ & $\begin{array}{c}(f 1 / 3 / 4) \\
(f \% 2 / 6 / 4)\end{array}$ & $\begin{array}{l}\text { "I do not know." } \\
\text { "This term does not mean anything to me." }\end{array}$ \\
\hline 2 & $\begin{array}{c}\text { Abstract } \\
\text { understanding }\end{array}$ & $\begin{array}{c}(f 26 / 16 / 41) \\
(f \% 45 / 30 / 37)\end{array}$ & $\begin{array}{l}\text { "Teaching about sustainability" } \\
\text { "Build the awareness about sustainability" } \\
\text { "The role of school is to educate for the future." } \\
\text { "Lessons, so that students can also deal with the concept of sustainability." } \\
\text { "To bring the so-called concepts closer to everyone, especially in school." } \\
\text { "To pass on sustainable development in schools - as a task for teachers." } \\
\text { "Teaching about ESD, following the trends in education." } \\
\text { "Is the education and teaching towards sustainability" } \\
\text { "Education creates an awareness of the necessity and feasibility of sustainability" }\end{array}$ \\
\hline
\end{tabular}


Table A2. Cont.

\begin{tabular}{|c|c|c|c|}
\hline NO & Category & $\begin{array}{c}\text { Number of Answers } \\
(f S I / A / T) \\
(f \% S I / A / T)\end{array}$ & Typical Answers \\
\hline 3 & $\begin{array}{l}\text { Environmental } \\
\text { education }\end{array}$ & $\begin{array}{c}(f 21 / 12 / 33) \\
(f \% 36 / 22 / 30)\end{array}$ & $\begin{array}{l}\text { "Environmental education for now and future generation." } \\
\text { "Education of specialists for ecological research areas." } \\
\text { "To make pupils aware that their behavior has a significant impact on the environment } \\
\text { and to show them ways to behave sustainably." } \\
\text { "Activating awareness and making people aware of problems that affect the future of our } \\
\text { environment." } \\
\text { "To show learners the sustainable use of resources, to motivate them to avoid garbage, e.g., } \\
\text { to buy 'second hand' goods, to replace plastic bags with paper or fabric bags, etc. Making } \\
\text { the consequences of 'waste' visible." } \\
\text { "Paying attention to environmental influences that are bad for the environment! Everyone } \\
\text { can do something! Ecological Footprint - Create awareness!" } \\
\text { "To motivate students to treat the environment in an environmentally friendly and } \\
\text { resource-conserving way." } \\
\text { "To make students aware that we have only one planet Earth and that we need to use the } \\
\text { given resources in the best possible way." } \\
\text { "Newly developed technologies/inventions with protection of the environment in mind." }\end{array}$ \\
\hline 4 & $\begin{array}{l}\text { Pedagogical } \\
\text { approach for } \\
\text { ESD }\end{array}$ & $\begin{array}{c}(10 / 23 / 33) \\
(f \% 17 / 43 / 30)\end{array}$ & $\begin{array}{l}\text { "Lifelong learning" } \\
\text { "Social and political development/education, rethinking and alternative actions." } \\
\text { "Learning by case studies" } \\
\text { "Offer seminars, workshops and in-depth discussions on the topic." } \\
\text { "To teach students values and competences so that they can also become part of } \\
\text { sustainable development." } \\
\text { "Sustainable thinking lives on a holistic level and must include the world in which the } \\
\text { students live. Therefore, sustainability issues need to be communicated to students on a } \\
\text { holistic level." } \\
\text { "To demonstrate cross-disciplinary awareness raising and options for action." } \\
\text { "To raise awareness and knowledge among students at school, but also among the } \\
\text { population through certain public events, in order to enable sustainable development and } \\
\text { the help of people." } \\
\text { "To educate students/children/people critically, to become critical citizens, to question } \\
\text { everything. e.g., Is Amazon good? No. Many do not know what is behind it." } \\
\text { "Education that enables learners to develop competences that are preserved throughout } \\
\text { their lives, thus opening up opportunities in many areas of life." } \\
\text { "To make future generations and/or adults aware of sustainability within the framework of } \\
\text { further training and to show them the possibility of becoming active themselves." }\end{array}$ \\
\hline & No answer & $\begin{array}{c}(f 2 / 6 / 8) \\
(f \% 3 / 10 / 13)\end{array}$ & \\
\hline
\end{tabular}

\section{References}

1. United Nations Educational, Scientific and Cultural Organization. Global Action Programme on Education for Sustainable Development Information Folder; UNESCO Bangkok Office: Bangkok, Thailand, 2015.

2. von Carlowitz, H.C. Sylvicultura Oeconomica oder Hauswirthliche Nachricht und Naturgemässe Anweisung zur wilden Baum-Zucht: Nebst Gründlicher Darstellung ... Grossen Holtz-Mangel ... zu Prospiciren ... Zugleich Eine gründliche Nachricht von den ... Gefunden Turff; Johann Freidrich Braun, 1713: Leipzig, Germany, 2000.

3. World Commission on Environment and Development. Our Common Future; Oxford University Press: Oxford, UK, 1987.

4. United Nations Conference on Environment and Development. Agenda 21, Rio Declaration, Forest Principles; United Nations Conference on Environment and Development: New York, NY, USA, 1992.

5. Palmer-Cooper, J.A. The Handbook of Environmental Education; Routledge: London, UK; New York, NY, USA, 1994; 280p.

6. Dedeurwaerdere, T. Sustainability Science for Strong Sustainability; Edward Elgar Pub. Ltd.: Cheltenham, UK, 2014; 176p.

7. Burmeister, M.; Eilks, I. German Chemistry student teachers' and trainee teachers' understanding of sustainability and education for sustainable development. Sci. Educ. Int. 2013, 24, 167-194.

8. Schultz, P. Inclusion with Nature: The Psychology of Human-Nature Relations; Springer: Boston, MA, USA, 2002; pp. 61-78.

9. Telesford, J.N.; Strachan, P.A. Strategic Sustainability Procedures: Focusing Business Strategic Planning on the Socio-Ecological System in an Island Context. Sustain. Dev. 2017, 25, 49. [CrossRef]

10. Sector, U.E. United Nations Decade of Education for Sustainable Development (2005-2014): International Implementation Scheme; UNESCO: Paris, France, 2005. 
11. Sterling, S. Higher Education, Sustainability and the Role of Systemic Learning; Springer: Dordrecht, The Netherlands, 2004; pp. 49-70.

12. Eijck, M.; Roth, W.-M. Improving Science Education for Sustainable Development. PLoS Biol. 2008, 5, e306. [CrossRef]

13. Hungerford, H. Environmental Education (EE) for the 21st Century: Where Have We Been? Where Are We Now? Where Are We Headed? J. Environ. Educ. 2009, 41, 1-6. [CrossRef]

14. Rieckmann, M. Education for Sustainable Development Goals: Learning Objectives; UNESCO Publishing: Paris, France, 2017.

15. Kopnina, H. Education for the future? Critical evaluation of education for sustainable development goals. J. Environ. Educ. 2020, 1-12. [CrossRef]

16. Selby, D. Education for sustainable development, nature and vernacular learning. CEPS J. 2017, 7, 9-27.

17. Paden, M. Education for Sustainability and Environmental Education; Springer: Boston, MA, USA, 2000; Volume 7, pp. 7-13.

18. de Haan, G.; Bormann, I.; Leicht, A. The Midway point of the UN Decade of Education for Sustainable Development: Where do we stand? Int. Rev. Educ. 2010, 56, 199-206. [CrossRef]

19. Büssing, A.; Schleper, M.; Menzel, S. Do Pre-service Teachers Dance with Wolves? Subject-Specific Teacher Professional Development in A Recent Biodiversity Conservation Issue. Sustainability 2019, 11, 47. [CrossRef]

20. Maina, F. Authentic Learning: Perspectives from Contemporary Educators. J. Authentic Learn. 2004, 1, 1-8.

21. Wood, W. Innovations in Teaching Undergraduate Biology and Why We Need Them. Annu. Rev. Cell Dev. Biol. 2009, 25, 93-112. [CrossRef]

22. Torkar, G. Learning experiences that produce environmentally active and informed minds. NJAS-Wageningen J. Life Sci. 2014, 69, 45-55. [CrossRef]

23. Schusler, T.; Krasny, M. Environmental Action as Context for Youth Development. J. Environ. Educ. 2010, 41, 208-223. [CrossRef]

24. Lotz-Sisitka, H.; Shumba, O.; Lupele, J.; Wilmot, D. Schooling for Sustainable Development in Africa; Springer International Publishing: Cham, Switzerland, 2017.

25. Franziska, B.; Christine, K.; Meret, L. Teachers' Competencies for the Implementation of Educational Offers in the Field of Education for Sustainable Development. Sustainability 2013, 5, 5080.

26. Rauch, F.; Steiner, R. Competences for Education for Sustainable Development in Teacher Education. CEPS J. 2013, 3, 9-24.

27. Hellberg-Rode, G.; Schrüfer, G. Welche spezifischen professionellen Handlungskompetenzen benötigen Lehrkräfte für die Umsetzung von Bildung für Nachhaltige Entwicklung (BNE)? ZDB-Biol. Lehren Und Lernen 2016, 20, 1-29.

28. Heinrich, M.; Rauch, F.; Minsch, J.; Schmidt, E.; Vielhaber, C. Bildung für Nachhaltige Entwicklung: Eine lernende Strategie für Österreich. Empfehlungen zu Reformen im Kontext der UNO-Dekade Bildung für Nachhaltige Entwicklung (2005-2014); Monsenstein und Vannerdat: Müenster, Germany, 2007.

29. Rauch, F.; Streissler, A.; Steiner, R. Kompetenzen für Bildung für Nachhaltige Entwicklung (KOM-BiNE); Bundesministerium für Unterricht, Kunst und Kultur: Wien, Austria, 2008.

30. Ministry of Education and Sport. White Paper on Education in the Republic of Slovenia; Ministry of Education and Sport: Ljubljana, Slovenia, 2011.

31. Vilhar, B.; Zupančič, G.; Gilčvert Bernik, D.; Vičar, M.; Zupan, A.; Sobočan, V.; Devetak, B.; Sojar, A. Učni načrt. Program osnovna šola. Biologija; Ministrstvo RS za šolstvo in šport, Zavod RS za šolstvo: Ljubljana, Sloveni, 2011.

32. Skvarč, M.; Vilhar, B. Učni Načrt: Program Osnovna Šola. Naravoslovje [National curriculum. Programme of basic education. Science.]; Ministrstvo za šolstvo in šport, Zavod RS za šolstvo: Ljubljana, Sloveni, 2011.

33. Wissenschaft und Forschung. Biologie und Umweltkunde; Bundesministerium für Bildung, Wissenschaft und Forschung: Wien, Austria, 2000.

34. Wissenschaft und Forschung. Biologie und Umweltkunde; Bundesministerium für Bildung, Wissenschaft und Forschung: Wien, Austria, 2008.

35. Lepičnik-Vodopivec, J. Vzgoja za trajnostni razvoj v praksi vrtcev. J. Elem. Educ. 2011, 4, 5-22.

36. Skribe-Dimec, D. Education for sustainable development in national tests: The case from Slovenia. Inov. Nastavi 2016, 29, 41-54. [CrossRef] 
37. Torkar, G. Live What You Teach \& Teach What You Live: Student Views on the Acceptability of Teachers' Value-Related Statements about Sustainability and Climate Change. CEPS J. 2013, 3, 45-58.

38. Kyburz-Graber, R.; Posch, P.; Peter, U. Challenges in Teacher Education-Interdisciplinarity and Environmental Education; StudienVerlag: Innsbruck, Austria, 2003.

39. Heinrich, M.; Mayr, P. ÖKOLOG-Oekologisierung von Schulen-Bildung für Nachhaltigkeit. In Analyse und Ausblick. Zusammenfassender Bericht über die Systematischen Reflexionen von Erfahrungen in den ÖKOLOG-Schulen; Pfaffenwimmer, G., BM:BWK/ENSI-Netzwerk, Eds.; Bundesministerium für Bildung Wissenschaft und Forschung: Wien, Austria, 2005.

40. Rauch, F.; Pfaffenwimmer, G. Education for Sustainable Development in Austria: Networking for Innovation; Springer: Cham, Switzerland, 2014; pp. 157-176.

41. Ucsnik, H. Die Implementierung der Bildung für Nachhaltige Entwicklung an Schulen in Österreich; University of Vienna: Vienna, Austria, 2010.

42. Summers, M.; Corney, G.; Childs, A. Student teachers' conceptions of sustainable development: The starting-points of geographers and scientists. Educ. Res. 2004, 46, 163-182. [CrossRef]

43. Ceulemans, G.; Eilks, I. Will Flemish Chemistry Teachers Soon Implement ESD? In Science education Research and Education for Sustainable Development; Shaker: Aachen, Germany, 2014; pp. 231-236.

44. Palmberg, I.; Hofman, M.; Jeronen, E.; Yli-Panula, E.; Palmberg, I.; Hofman-Bergholm, M.; Jeronen, E.; Yli-Panula, E. Systems Thinking for Understanding Sustainability? Nordic Student Teachers' Views on the Relationship between Species Identification, Biodiversity and Sustainable Development. Educ. Sci. 2017, 7, 72. [CrossRef]

45. Maurer, M.; Bogner, F. How freshmen perceive Environmental Education (EE) and Education for Sustainable Development (ESD). PLoS ONE 2019, 14, e0208910. [CrossRef] [PubMed]

46. Kioupi, V.; Voulvoulis, N. Education for Sustainable Development: A Systemic Framework for Connecting the SDGs to Educational Outcomes. Sustainability 2019, 11, 6104. [CrossRef]

47. Corbin, J.M.; Strauss, A.L. Basics of Qualitative Research: Techniques and Procedures for Developing Grounded Theory, 4th ed.; 431 Seiten, Diagramme, 423 cm; SAGE: Thousand Oaks London, UK, 2015; p. xviii.

48. Kopnina, H. Ecocentric Education: Student Reflections on Anthropocentrism-Ecocentrism Continuum and Justice. J. Educ. Sustain. Dev. 2019, 13, 5-23. [CrossRef]

49. OECD, S.; Paris, M. Measuring Distance to the SDG Targets: An Assessment of Where OECD Countries Stand. Available online: https://www.oecd-ilibrary.org/sites/a8caf3fa-en/index.html?itemId=/content/publication/ a8caf3fa-en (accessed on 25 August 2020).

50. Hagevik, R.; Jordan, C.; Wimert, D. A Phenomenographic Study of Beginning Elementary Science Teachers' Conceptions of Sustainability. In Educating Science Teachers for Sustainability; Springer: Cham, Switzeland, 2015; pp. 17-29.

51. Uitto, A.; Saloranta, S. Subject Teachers as Educators for Sustainability: A Survey Study. Educ. Sci. 2017, 7, 8. [CrossRef]

(C) 2020 by the authors. Licensee MDPI, Basel, Switzerland. This article is an open access article distributed under the terms and conditions of the Creative Commons Attribution (CC BY) license (http://creativecommons.org/licenses/by/4.0/). 